Jurnal Penelitian dan Evaluasi Pendidikan

\title{
PENGUKURAN KEMAMPUAN BELAJAR MANDIRI PADA MAHASISWA PENDIDIKAN PROFESI DOKTER
}

\author{
Eti Poncorini Pamungkasari, Ari Probandari \\ Fakultas Kedokteran Universitas Sebelas Maret \\ etiponcouns@yahoo.com, ariprobandari@yahoo.com
}

\begin{abstract}
Abstrak
Kemampuan belajar mandiri adalah otonomi pembelajar dalam mengontrol proses pembelajarannya. Kemampuan belajar mandiri bisa dikembangkan dalam proses pembelajaran. Penelitian terdahulu tentang pembelajaran pendidikan profesi dokter menyatakan masih adanya hambatan dalam kemampuan belajar mandiri mahasiswa. Tujuan penelitian ini adalah mengetahui perbedaan kemampuan belajar mandiri mahasiswa tahap pendidikan profesi sebelum dan sesudah menjalani pembelajaran di suatu departemen klinik. Penelitian ini merupakan penelitian observasional dengan pendekatan comparative cross sectional. Subjek penelitian adalah mahasiswa pendidikan profesi dokter yang menjalani pendidikan profesi di satu bagian dengan masa pembelajaran 4 minggu, selama AgustusSeptember 2012, sejumlah 33 orang, dengan teknik purposif sampling. Lokasi penelitian di salah satu rumah sakit pendidikan di Surakarta. Instrumen yang digunakan merupakan alih bahasa dan modifikasi kuesioner yang dikembangkan oleh Fischer, King dan Tague tahun 2001. Analisis data dilakukan dengan uji-t. Hasil penelitian menunjukkan tidak ada perbedaan yang signifikan secara statistik antara rerata kemampuan belajar mandiri mahasiswa sebelum $(149,6)$ dan sesudah $(151,9)$ menjalani pembelajaran tahap pendidikan profesi di satu bagian pendidikan profesi dokter $(p=0,47)$. Ini berarti tidak ada perbedaan yang signifikan secara statistik antara kemampuan belajar mandiri mahasiswa sebelum dan sesudah menjalani pembelajaran tahap pendidikan profesi di satu departemen. Perlu penelitian lebih lanjut tentang alternatif intervensi yang perlu dilakukan untuk meningkatkan kemampuan belajar mandiri mahasiswa dalam pembelajaran profesi dokter.
\end{abstract}

Kata kunci: kemampuan belajar mandiri, pendidikan profesi dokter, mahasiswa pendidikan profesi dokter

492 - Jurnal Penelitian dan Evaluasi Pendidikan Tahun 16, Nomor 2, 2012 


\title{
MEASUREMENT ON SELF-STUDY PERFORMANCE OF MEDICAL EDUCATION PROFESSIONALS STUDENT
}

\author{
Eti Poncorini Pamungkasari, Ari Probandari \\ Fakultas Kedokteran Universitas Sebelas Maret \\ etiponcouns@yahoo.com, ariprobandari@yahoo.com
}

\begin{abstract}
The ability of self directed learning is learners' autonomy to control their learning process. The ability to perform self-directed learning can be developed during the learning process. Previous studies showed potential barriers to perform self-directed learning among medical students. This study aimed to analyse difference of self-directed learning ability among medical students before and after undergoing professional education program in a certain clinical department.This study was an observational study with comparative cross-sectional approach. The subjects were medical students on the professional education program at a certain clinical department at a teaching hospital Surakarta city. Thirty-three students undergoing a 4-week program from August to September 2012, were selected by purposive sampling. The instrument used from Fischer, King and Tague was further translated into Bahasa Indonesia and validated. Data was analysed using t-test. The study found no statistically significant difference on average self-directed learning ability before $(149,6)$ and after $(151,9)$ following the professional education program at a certain clinical department $(p=0,47)$. More studies are needed particularly to investigate alternatives of interventions to increase self-directed learning ability in the professional phase of medical education.
\end{abstract}

Keywords: self-directed learning, medical professional education, medical students 


\section{Pendahuluan}

Kemampuan belajar mandiri merupakan salah satu karakteristik yang dibutuhkan dalam pembelajaran orang dewasa. Teori-teori yang mendukung tentang pembelajaran orang dewasa, dapat diklasifikasikan dalam lima hal yaitu instrumental learning, self-directed learning, eksperiential learning, perspective transformation dan situated cognition. Asumsi yang mendasari pembelajaran orang dewasa adalah kebebasan dan pengaturan diri, telah mempunyai berbagai tingkat pengalaman, mengintegrasikan pembelajaran menjadi kebutuhan sehari-hari, lebih tertarik pada pendekatan pemecahan masalah, lebih termotivasi secara internal daripada eksternal (Abela, 2009).

Kemampuan belajar mandiri dapat diartikan sebagai otonomi pembelajar dalam mengontrol proses pembelajaran yang dijalaninya. Pembelajaran diharapkan lebih efektif dan fokus dengan kemampuan belajar mandiri ini. Otonomi yang dimiliki pebelajar ini bukan merupakan status permanen, dapat berubah pada perbedaan waktu dan area pembelajaran. Hal lain yang dapat berpengaruh pada kemampuan belajar mandiri antara lain kepribadian, konteks budaya dan pengalaman belajar yang telah dilalui sebelumnya. Dosen mempunyai peran yang penting dalam mengembangkan kemampuan belajar mandiri mahasiswa, misalnya dengan pemilihan strategi pembelajaran yang digunakan (Thornton, 2009).

Kemampuan belajar mandiri sangat penting dalam pendidikan kedokteran untuk memberi bekal lulusan menjadi seorang pebelajar seumur hidup. Komponen kunci dalam kemampuan belajar mandiri antara lain adalah: peran dosen sebagai fasilitator, identifikasi kebutuhan belajar, pengembangan tujuan pembelajaran, identifikasi sumber yang sesuai, implementasi proses, komitmen pada kontrak dan evaluasi pembelajaran. Aplikasi belajar mandiri dalam pendidikan kedokteran dan kesehatan mempunyai keterbatasan dengan sangat beragamnya implementasi dan pendefinisian tentang kemampuan belajar mandiri oleh dosen (Murad dan Varkey, 2008).

Pendidikan dokter di Indonesia terbagi menjadi dua tahap yang berkesinambungan, yaitu pendidikan tahap sarjana kedokteran dan tahap profesi. Di Fakultas Kedokteran UNS, tahap sarjana kedokteran ditempuh 
selama tujuh semester menggunakan kurikulum berbasis kompetensi dengan problem based learning bybrid, pembelajaran terbagi dalam 27 blok. Tahap pendidikan profesi ditempuh setelah menyelesaikan tahap sarjana kedokteran selama tiga semester. Tahap pendidikan profesi merupakan tahap yang penting karena mahasiswa akan mendapatkan kesempatan berinteraksi secara langsung dengan pasien dibawah supervisi dosen pembimbing klinik. Pada tahap pendidikan profesi, mahasiswa dapat mempraktekkan ilmu yang telah didapatkan pada tahap sebelumnya (Bansal, 2004; Tsai et al., 2007). Teori yang telah didapat pada tahap pendidikan sarjana akan sulit untuk diterapkan oleh mahasiswa tanpa pembelajaran tahap profesi (Hays, 2005).

Saat ini inovasi pendidikan kedokteran telah banyak dilakukan di Indonesia termasuk di Fakultas Kedokteran UNS, misalnya dengan problem based learning (PBL) yang diaplikasikan pada kurikulum berbasis kompetensi tingkat sarjana kedokteran. Namun demikian belum banyak inovasi yang dilakukan pada tahap pendidikan profesi. Pendidikan profesi dokter sebenarnya perlu memperhatikan kesinambungan kurikulum dengan kurikulum tahap sarjana kedokteran termasuk didalamnya metode pembelajaran yang digunakan (Cox dan Irby, 2007). Dengan kesinambungan ini diharapkan mengurangi masalah-masalah yang akan timbul dalam proses pembelajaran.

Pada tahap pendidikan profesi masih ditemui masalah-masalah yang menyangkut kemampuan belajar mandiri mahasiswa, seperti yang ditunjukkan dari penelitian kualitatif yang dilakukan O'Brien, Cooke dan Arby tahun 2005 dan 2006 di 10 Fakultas Kedokteran di Amerika. Penelitian tersebut mendapatkan bahwa mahasiswa pendidikan profesi menghadapi hambatan berupa pemahaman peran dan tanggung jawab, ketrampilan klinis, mempelajari situasi pembelajaran klinik, dan hal lain seperti dosen pembimbing klinik, staf (perawat, bidan dan lain-lain) dan materi. Dosen pembimbing klinik menyatakan ada kesulitan mahasiswa dalam mengaplikasikan pengetahuan ilmu kedokteran yang telah diperoleh di tahap sebelumnya pada pendidikan klinis dengan kasus nyata, kesulitan dalam clinical reasoning, kemampuan belajar mandiri dan penilaian terhadap diri sendiri. Mahasiswa dan dosen pembimbing klinik sama-sama sepakat 
ada hambatan pembelajaran di tahap pendidikan profesi yang berhubungan dengan kemampuan belajar mandiri mahasiswa (O Brien, Cooke dan Irby, 2007).

Pendidikan profesi secara departemental saat ini masih banyak dilakukan di Indonesia, termasuk di Fakultas Kedokteran UNS. Mahasiswa akan mengikuti suatu rotasi klinik, melewati beberapa departemen. Urutan departemen yang dilewati dapat berbeda-beda tiap mahasiswa, tergantung departemen mana yang pada saat mahasiswa itu akan masuk dapat ditambah jumlah mahasiswanya. Mahasiswa satu angkatan yang sama, tidak memasuki rotasi klinik secara bersamaan, tergantung waktu kelulusan tahap sarjana kedokteran tiap mahasiswa. Syarat untuk dapat memasuki rotasi klinik adalah mahasiswa telah menyelesaikan tahap sebelumnya yaitu tahap pendidikan sarjana kedokteran.

Di Fakultas Kedokteran UNS, tahap pendidikan profesi terdiri dari 16 departemen. Waktu tempuh tiap departemen berbeda-beda, misalnya bagian ilmu kesehatan anak selama 8 minggu, ilmu penyakit kulit 4 minggu. Untuk menyelesaikan seluruh departemen ini dalam rotasi klinik dibutuhkan waktu 18 bulan. Kegiatan yang dilakukan di berbagai macam departemen tersebut secara umum hampir sama, antara lain bedside teaching, konferensi kasus, jurnal reading. Mahasiswa pendidikan profesi dokter juga mendapatkan tugas jaga malam secara bergantian.

Pada saat menempuh pendidikan profesi, mahasiswa akan dibimbing oleh dosen pembimbing klinik. Dosen pembimbing klinik adalah staf pada tiap departemen baik yang mempunyai status pegawai kementrian pendidikan nasional maupun kementrian kesehatan dan pegawai pemerintah propinsi dan daerah. Misalnya di bagian penyakit dalam, maka dosen pembimbing klinik adalah dokter spesialis penyakit dalam yang bertugas di departemen tersebut. Dosen pembimbing klinik disamping bertugas membimbing mahasiswa pendidikan profesi, juga mempunyai tugas-tugas lain, yaitu pelayanan pada pasien rumah sakit, membimbing mahasiswa pendidikan dokter spesialis dan mengajar, menjadi tutor dan instruktur skills lab mahasiswa tahap pendidikan sarjana kedokteran. Dengan banyaknya tugas yang harus dilaksanakan oleh dosen pembimbing 
klinik ini, maka sering ada kesulitan dalam hal pengalokasian waktu membimbing mahasiswa pendidikan profesi.

Selain sulitnya pengalokasian waktu dosen pembimbing klinik, hal lain yang sering menjadi hambatan dalam pembelajaran tahap pendidikan profesi dokter adalah jumlah pasien dan makin banyaknya tingkatan pendidikan yang menempuh pendidikan di rumah sakit yang sama, misalnya mahasiswa program pendidikan dokter spesialis. Mahasiswa tahap pendidikan profesi lebih banyak bersama mahasiswa program pendidikan dokter spesialis (PPDS), sehingga biasanya mahasiswa tersebut meminta bimbingan materi pada mahasiswa pendidikan dokter spesialis. Keadaan seperti ini juga terjadi di negara lain, seperti China, dilaporkan oleh Chen dkk (2008). Penelitian tersebut menyimpulkan mahasiswa fakultas kedokteran tahap pendidikan profesi lebih sering diamati oleh mahasiswa PPDS dibandingkan staf pengajar (dosen klinik). Namun karena mahasiswa PPDS merasa mempunyai tanggung jawab utama adalah belajar, maka bimbingan yang diberikan juga tidak intensif. Tidak jarang terjadi mahasiswa kepaniteraan klinik harus berebut kasus dengan mahasiswa PPDS tingkat awal. Hal ini tentunya bisa mengancam pencapaian kompetensi mahasiswa kepaniteraan klinik, karena pada kasus yang seharusnya mereka bisa menangani langsung kadang hanya bisa melihat saja, terutama bila mahasiswa tersebut termasuk dalam kategori mahasiswa pasif. Mahasiswa banyak yang merasa gamang tentang ketrampilan mereka untuk praktek menjadi dokter nanti, karena pada satu ketrampilan, mereka hanya berlatih satu atau dua kali pada pasien (Fischer et al., 2007).

Berdasar latar belakang tersebut, masih ada masalah tentang kemampuan belajar mandiri mahasiswa di tahap pendidikan profesi dokter, dan belum banyak dilakukan inovasi pembelajaran pada tahap profesi dokter, serta hambatan-hambatan yang terjadi pada pembelajaran profesi dokter maka penelitian ini dilakukan. Tujuan penelitian ini adalah untuk mengetahui adakah perbedaan kemampuan belajar mandiri mahasiswa tahap pendidikan profesi sebelum dan sesudah menjalani pembelajaran di suatu bagian dengan pembelajaran apa adanya (konvensional), tanpa inovasi metode pembelajaran. Manfaat dari penelitian ini diharapkan dapat 
memberikan masukan bagi pengembangan kurikulum tahap pendidikan profesi dokter.

\section{Metode Penelitian}

Penelitian ini merupakan penelitian observasional dengan pendekatan comparative cross-sectional. Penelitian dilakukan di salah satu rumah sakit pendidikan di Surakarta. Rumah sakit pendidikan tersebut juga digunakan untuk pembelajaran mahasiswa pendidikan dokter spesialis pada beberapa departemen. Subjek penelitian adalah mahasiswa pendidikan profesi dokter. Teknik sampling dilakukan secara purposif, untuk memilih mahasiswa yang menjalani pendidikan profesi di satu departemen dengan masa pembelajaran empat minggu, selama pengambilan data, yaitu Agustus-September 2012. Penelitian ini hanya dilakukan pada satu departemen saja untuk menghindari bias yang dapat mempengaruhi hasil penelitian, misalnya perbedaan metode dan strategi belajar mengajar di tiap departemen dan perbedaan lama tempuh departemen. Selama waktu pengambilan data ini hanya ada sejumlah 33 orang mahasiswa yang menempuh pendidikan profesi di departemen tersebut. Jumlah anggota sampel dianggap cukup memenuhi dengan kriteria penentuan minimal besar sampel dengan rule of thumb (Murti, 2006). Selama ini jumlah dan nama mahasiswa yang memasuki suatu departemen di pendidikan profesi diatur oleh bagian rotasi klinik Fakultas Kedokteran UNS.

Instrumen yang digunakan adalah alih bahasa dan modifikasi kuesioner kemampuan belajar mandiri mahasiswa yang dikembangkan oleh Fischer, King dan Tague tahun 2001. Alasan pemilihan instrumen ini adalah, instrumen ini dikembangkan untuk mengukur kemampuan belajar mandiri pada mahasiswa keperawatan, yang termasuk dalam kelompok ilmu kesehatan. Instrumen yang terdiri dari 40 butir ini disusun dalam skala likert, merupakan instrumen yang bersifat self-report. Instrumen ini pernah diuji reliabilitas oleh peneliti di tahun 2010 dengan nilai alpha croncbach 0,95. Pengukuran dengan instrumen ini dilakukan dua kali, pada minggu pertama dan minggu terakhir mahasiswa berada pada departemen tersebut. Analisis data dilakukan dengan uji-t. 


\section{Hasil dan Pembahasan}

Penelitian ini melibatkan 33 responden dengan karakteristik seperti pada Tabel 1.

Tabel 1. Karakteristik responden penelitian $(\mathrm{n}=33)$

\begin{tabular}{|l|l|l|}
\hline \multicolumn{2}{|l|}{ Karakteristik } & Frekuensi (\%) \\
\hline \multirow{3}{*}{ Jenis kelamin } & Laki-laki & $11(33 \%)$ \\
\cline { 2 - 3 } & Perempuan & $22(67 \%)$ \\
\hline Angkatan masuk FK & 2001 & $1(3 \%)$ \\
\cline { 2 - 3 } & 2004 & $1(3 \%)$ \\
\cline { 2 - 3 } & 2005 & $1(3 \%)$ \\
\cline { 2 - 3 } & 2006 & $3(9,1 \%)$ \\
\cline { 2 - 3 } & 2007 & $20(60,6 \%)$ \\
\cline { 2 - 3 } & 2008 & $7(21,2 \%)$ \\
\hline \multirow{5}{*}{ Tempat tinggal } & Orang tua & $8(24,3 \%)$ \\
\cline { 2 - 3 } & Kos & $23(69,7 \%)$ \\
\cline { 2 - 3 } & Saudara & $1(3 \%)$ \\
\cline { 2 - 3 } & Lainnya & $7(21.2 \%)$ \\
\hline \multirow{5}{*}{$\begin{array}{l}\text { Lama menempuh } \\
\text { rotinik }\end{array}$} & $1-6$ bulan & $2(6.1 \%)$ \\
\cline { 2 - 3 } & $7-12$ bulan & $2(6.1 \%)$ \\
\cline { 2 - 3 } & $13-18$ bulan & \\
\cline { 2 - 3 } & lebih dari 18 bulan & $1(3 \%)$ \\
\hline
\end{tabular}

Mayoritas mahasiswa kedokteran yang menempuh tahap pendidikan profesi yang menjadi sampel dalam penelitian ini adalah perempuan. Sebagian besar dari sampel tinggal di rumah kos dan telah menempuh pendidikan profesi selama lebih dari satu tahun (Tabel 1). 
Tabel 2. Deskripsi kemampuan belajar mandiri mahasiswa pretes dan postes

\begin{tabular}{|l|c|c|c|}
\hline Skor & Minimal & Maksimal & Rerata \\
\hline $\begin{array}{l}\text { Kemampuan belajar mandiri } \\
\text { sebelum menempuh pembelajaran } \\
\text { tahap profesi }\end{array}$ & 133 & 194 & 149,6 \\
\hline $\begin{array}{l}\text { Kemampuan belajar mandiri } \\
\text { sesudah menempuh pembelajaran } \\
\text { tahap profesi }\end{array}$ & 120 & 184 & 151,9 \\
\hline
\end{tabular}

Nilai rerata kemampuan belajar mandiri sesudah menempuh pembelajaran tahap profesi lebih tinggi dari nilai sebelumnya (tabel 2). Pengolahan data dengan uji-t didapatkan nilai $t=-0,741, p=0,47$. Dengan demikian tidak ada perbedaan yang signifikan secara statistik kemampuan belajar mandiri mahasiswa sebelum dan sesudah menjalani pembelajaran tahap pendidikan profesi di salah satu departemen pendidikan profesi. Dilakukan juga uji korelasi antara lama menjalani rotasi klinik dengan kemampuan belajar mandiri sebelum masuk bagian tersebut. Hasil uji korelasi pearson menunjukkan angka korelasi $=-0,089, \mathrm{p}=0,623$. Jadi, ada korelasi lemah yang negatif antara lama menjalani rotasi klinik dengan kemampuan belajar mandiri mahasiswa.

Hasil penelitian ini menyatakan tidak ada perbedaan yang signifikan antara kemampuan belajar mandiri mahasiswa sebelum dan sesudah menjalani pembelajaran tahap pendidikan profesi. Pembelajaran yang dilakukan tersebut merupakan pembelajaran apa adanya, yang biasa dilakukan pada tahap pendidikan profesi, tanpa adanya inovasi-inovasi yang dilakukan untuk meningkatkan efektifitas pembelajaran. Pada tahap pendidikan profesi dokter, kegiatan pembelajaran yang dilakukan antara lain bedside teaching, jurnal reading, dan konferensi kasus. Pembimbing klinik di rumah sakit pendidikan mempunyai banyak tugas rutin yang harus dikerjakan, tidak hanya membimbing mahasiswa tahap profesi dokter, tetapi juga pelayanan pada pasien dan membimbing mahasiswa pendidikan 
dokter spesialis. Sempitnya waktu yang dapat digunakan untuk membimbing mahasiswa pendidikan profesi ini sering menyebabkan pembelajaran berjalan secara spontan dan tanpa terencana, misalnya tanpa terlebih dahulu menentukan tujuan pembelajaran yang ingin dicapai pada saat akan melaksanakan bedside teaching. Perlu dilakukan inovasi-inovasi, terutama agar tujuan dan metode pembelajaran dapat menumbuhkan kemampuan belajar mandiri pada mahasiswa. Dalam mengimplementasikan proses belajar yang akan menunjang pengembangan kemampuan belajar mandiri, dosen sebagai fasilitator perlu membuat pertemuan awal dengan mahasiswa sebelum memulai proses pembelajaran. Pertemuan ini menekankan hubungan yang setara antara dosen dan mahasiswa, bukan ketergantungan mahasiswa pada dosen. Kemudian pada pertemuan-pertemuan dosen dan mahasiswa perlu dilakukan identifikasi kebutuhan belajar, tujuan, rencana pembelajaran dan evaluasi. Pada pebelajar dengan kemampuan belajar mandiri yang kurang, maka model pembelajaran kooperatif, seperti yang telah banyak dilakukan dan dilaporkan dalam studi tentang pendidikan keperawatan bisa dilakukan (Murad dan Varkey, 2008).

Hal lain yang menarik pada tahap pendidikan profesi adalah mulai berkurangnya jumlah pasien di rumah sakit pendidikan dibandingkan rasio mahasiswa, sehingga otomatis kesempatan mahasiswa untuk menangani pasien secara langsung mulai berkurang. Melihat kondisi tahap pendidikan profesi saat ini, seharusnya mahasiswa mempunyai kemampuan belajar mandiri yang cukup, untuk mengimbangi hal-hal yang bisa menghambat pencapaian kompetensinya. Hal ini tidak hanya terjadi di Indonesia. Tantangan pendidikan tahap profesi dokter di Amerika adalah terbatasnya waktu dan dana pendidikan yang membuat pendidikan profesi mulai kurang diperhatikan (Reilly, 2007). Berdasar hasil penelitian tersebut maka pemilihan metode pembelajaran yang sesuai, pengaturan kualitas bimbingan mengingat waktu dosen yang terbatas, dan peningkatan kemampuan dosen dapat menjadi alternatif bagi inovasi pembelajaran profesi.

Dalam rangka pengembangan pendidikan tahap profesi, maka penting melihat pada hasil penelitian terdahulu tentang pembelajaran tahap 
profesi. Penelitian yang dilakukan oleh Al Haqwi dan kawan-kawan di Arab Saudi, mengidentifikasi pendapat mahasiswa mengenai faktor yang mempengaruhi pembelajaran tahap profesi mereka. Hasil penelitian tersebut menyebutkan faktor yang mempengaruhi keberhasilan pembelajaran tahap profesi adalah penyediaan pengalaman pembelajaran klinik yang nyata, organisasi yang baik pada sesi pembelajaran klinik, kasus klinik yang dipilih, supervisi yang baik dan kemampuan belajar mahasiswa (Al Haqwi, 2010).

Penyediaan pengalaman pembelajaran klinik yang nyata pada pendidikan profesi dokter terkait dengan jumlah dan variasi kasus pasien. Pada situasi dan kondisi saat ini dengan jumlah dan variasi kasus pasien mungkin terbatas, banyak hal yang bisa dilakukan antara lain misalnya dengan pasien simulasi atau penggunaan audio visual (pemutaran video tentang kasus pasien), mendiskusikan kasus-kasus yang jarang namun penting pada konferensi kasus atau jurnal reading. Namun demikian, perlu disadari bahwa dengan sangat banyaknya jumlah kasus penyakit di bidang kedokteran tidak akan mungkin semuanya dapat dipelajari oleh seseorang selama menempuh pendidikan. Perkembangan ilmu dan teknologi kedokteran sangat pesat. Untuk itulah pendidikan kedokteran saat ini lebih menekankan pada kemampuan belajar mandiri mahasiswa sebagai senjata untuk belajar seumur hidup yang harus dilakukan oleh seorang dokter. Dokter tidak hanya mempunyai kewajiban belajar saat menjadi mahasiswa kedokteran saja, tetapi setelah lulus dari pendidikan, seorang dokter tetap mempunyai kewajiban belajar.

Kurikulum merupakan salah satu hal yang dapat mempengaruhi perkembangan kemampuan belajar mandiri mahasiswa. Penelitian tentang ini telah dilakukan di Inggris tentang persepsi lulusan fakultas kedokteran yang menjalani kurikulum baru dengan problem based learning. Dokter yang telah 6 tahun lulus dari fakultas kedokteran tersebut merasakan bahwa dengan kurikulum yang baru tersebut, mereka merasa mempunyai kemampuan belajar mandiri yang cukup baik (Watmough, O'Sullivan dan Taylor, 2010). Untuk tahap pendidikan profesi perlu dieksplorasi lebih lanjut kurikulum dan metode pembelajaran apa saja yang dapat mengembangkan kemampuan belajar mandiri. 
Review yang dilakukan oleh Nara, Suzuki dan Tohda menyebutkan bahwa kuantitas pengetahuan yang sangat banyak dalam ilmu kedokteran tidak akan memungkinkan untuk dapat dikuasai semua dalam masa pendidikan. Namun hal ini tidak perlu dikhawatirkan, karena teknologi informasi sudah demikian pesat. Seseorang dapat mencari dengan mudah informasi yang dibutuhkannya melalui internet. Tetapi proses ini juga membutuhkan ketrampilan, karena tidak semua informasi yang ada di internet dapat digunakan sebagai sumber referensi. Kemampuan belajar mandiri juga sangat penting dalam proses ini, karena dengan adanya kemampuan belajar mandiri, seseorang dapat menyadari apa yang dibutuhkan, dimana dan bagaimana harus mencarinya. Untuk mengembangkan kemampuan belajar mandiri ini, bisa dilakukan antara lain dengan tutorial problem based learning yang saat ini telah banyak dilakukan oleh fakultas kedokteran di Indonesia pada tahap pendidikan sarjana kedokteran. Pengembangan pembelajaran mandiri merupakan salah satu hal yang sedang menjadi perhatian pada pendidikan kedokteran di seluruh dunia (Nara, Suzuki dan Tohda, 2011).

Untuk mengembangkan pembelajaran menjadi lebih efektif, perlu dilihat sumber daya yang terlibat dalam pembelajaran tahap profesi. Mahasiswa, dokter pembimbing klinik dan pasien merupakan tiga kelompok sumber daya manusia dalam pembelajaran tahap profesi. Tiga kelompok ini mempunyai keterikatan satu sama lain dalam suatu hubungan yang bertanggungjawab. Untuk memahami pembelajaran di pendidikan tahap profesi, pendekatan teori sosial kognitif dan teori tentang pengembangan procedural knowledge bisa digunakan. Contoh penerapan teori sosial kognitif pada tahap pendidikan profesi ini adalah mahasiswa akan menguasai suatu ketrampilan dengan melihat atau melakukan observasi terlebih dahulu, kemudian menirukan (Omrod, 2009). Walaupun pada pembelajaran orang dewasa mahasiswa perlu mempunyai otonomi terhadap pembelajarannya, tetapi pendidikan tahap profesi memerlukan kesesuaian sesuai tahap mahasiswa. Pada pendidikan kedokteran terjadi pengembangan procedural knowledge, contohnya seorang mahasiswa setelah lulus nanti diharapkan menguasai langkah-langkah penanganan pasien. Konsep procedural knowledge ini, di awal pembelajaran seorang pebelajar akan 
melakukan sesuatu hal dengan perlahan-lahan, dan memerlukan konsentrasi penuh. Dengan latihan yang berulang-ulang maka prosedur tersebut akan dilakukan dengan lebih cepat, mudah dan efisien (Omrod, 2009). Dengan memahami teori-teori ini maka diharapkan dosen dan mahasiswa dapat menemukan pola hubungan yang sesuai, sehingga tidak mematikan otonomi mahasiswa namun dosen juga tetap berperan sebagai fasilitator yang baik dalam pembelajaran. Misalnya untuk mahasiswa yang baru pertama kali mengikuti pembelajaran tahap profesi tentunya akan lebih bergantung pada dosen. Dosen harus menunjukkan bagaimana cara melakukan anamnesis, pemeriksaan dan lain-lain pada mahasiswa secara benar, sebelum mahasiswa tersebut dapat menirukan dan kemudian melakukan sendiri dibawah supervisi. Perkembangan tahap pembelajaran mahasiswa ini dapat diketahui oleh dosen pembimbing dengan beberapa alat, salah satunya adalah tulisan/catatan refleksi (Abela, 2009).

Murrad dan Varkey menyatakan adanya komponen kunci untuk kemampuan belajar mandiri mahasiswa. Komponen-komponen itu antara lain: dosen sebagai fasilitator, identifikasi kebutuhan belajar, pengembangan tujuan pembelajaran, identifikasi sumber belajar yang sesuai, implementasi proses, komitmen pada kontrak pembelajaran dan evaluasi pembelajaran. Dosen atau sering disebut sebagai pembimbing klinik mempunyai peran yang penting dalam mengembangkan kemampuan belajar mandiri mahasiswa (Murrad \& Varkey, 2008). Pembimbing klinik yang baik semestinya bisa menjadi model bagi mahasiswa baik dalam hal ketrampilan klinis maupun kepribadian. Pembimbing klinik yang baik harus menguasai prinsip pembelajaran orang dewasa, humanitarian, berpikiran luas dan terbuka dan mempunyai semangat untuk membimbing. Interaksi yang baik dengan dokter dan profesi pendukung yang lain seperti perawat serta sesama mahasiswa sangat dibutuhkan dalam kelancaran proses pembelajaran klinis (Dornan, 2006; Hays, 2005). Pembimbing klinik perlu menjadi seorang yang inovatif, mendidik pengetahuan dan ketrampilan mahasiswa dan juga dapat berperan sebagai role model, mendidik nilai-nilai profesionalisme (Sutkin et al., 2008). Pembimbing klinik harus mempunyai kemampuan untuk mengaktifkan mahasiswa dalam proses belajar mengajar (Reilly, 2007).

504 - Jurnal Penelitian dan Evaluasi Pendidikan Tahun 16, Nomor 2, 2012 
Bila melihat karakteristik mahasiswa pendidikan profesi dokter (tabel 1) Sebagian besar mahasiswa mempunyai riwayat pendidikan tahap sarjana dengan kurikulum PBL hybrid, yaitu sebanyak 27 mahasiswa. Fakultas Kedokteran UNS mulai tahun 2007, menerapkan PBL hybrid. Pada PBL hybrid ini masih dilakukan kuliah-kuliah penunjang berisi materi-materi dalam blok tersebut yang dianggap sulit muncul dalam diskusi skenario tutorial, dan harus diikuti mahasiswa. Praktikum juga masih menjadi kegiatan pembelajaran yang wajib diikuti. Pada PBL murni tidak ada lagi kuliah penunjang, ada kuliah panel atau kuliah pakar di akhir blok dengan tujuan mendiskusikan hal yang belum terjawab pada diskusi tutorial dan menyamakan persepsi seluruh kelompok mahasiswa. Praktikum, pada PBL murni merupakan kegiatan yang tidak wajib, mahasiswa yang merasa tidak memerlukan praktikum karena merasa pengetahuannya telah cukup boleh tidak mengikuti praktikum. Penelitian sebelumnya tentang pengaruh penerapan PBL hybrid terhadap kemampuan belajar mandiri mahasiswa sudah banyak dilakukan, tetapi masih terdapat perbedaan hasil. Misalnya, penelitian yang dilakukan oleh Devi et al. di India, menemukan bahwa kemampuan belajar mandiri mahasiswa yang menempuh kurikulum PBL hybrid lebih rendah dari mahasiswa dengan kurikulum tradisional (Devi et al., 2012). Berbeda dengan penelitian yang dilakukan di Kanada, menyebutkan bahwa penerapan PBL hybrid dapat mempengaruhi kemampuan belajar mandiri mahasiswa (Lee, Mann \& Frank, 2010). Adanya perbedaan hasil penelitian ini sangat wajar karena tentu ada perbedaan model PBL hybrid, strategi, jenis dan karakter staf pengajar dan mahasiswa, serta sarana prasarana pendidikan pada berbagai tempat. Faktor lain yang cukup penting adalah bagaimana proses PBL hybrid dilaksanakan, misalnya apakah tes yang digunakan untuk menentukan kelulusan mahasiswa cukup mampu untuk memacu kemampuan belajar mandiri mahasiswa. Penelitian lain yang dilakukan di Inggris, meneliti tentang persepsi dokter lulusan kurikulum PBL tentang diri mereka, menyatakan bahwa dokter-dokter lulusan PBL merasa mempunyai kemampuan belajar mandiri yang cukup, dan merasa dipersiapkan dengan baik untuk menjadi seorang dokter (Watmough, O’Sullivan \& Taylor, 2010). 
Hasil penelitian ini mengindikasikan perlu inovasi pembelajaran pada tahap profesi dokter. Seperti dikemukakan oleh Abela, saat ini diperlukan pengembangan pembelajaran pada bidang pendidikan kedokteran ke arah pembelajaran transformatif (transformative learning). Dengan transformatif learning ini diharapkan meningkatkan pembelajaran orang dewasa dan dapat membuat pembelajaran lebih efektif. Salah satu yang disarankan adalah dengan metode pembelajaran reflektif yang akan mempengaruhi motivasi belajar (Abela, 2009). Pembelajaran tahap profesi merupakan proses pembelajaran aktif dan eksperiensial. Kesuksesan proses ini sangat tergantung pada kapasitas mahasiswa dalam refleksi dan keakuratan penilaian diri sendiri. Tiap mahasiswa mungkin mempunyai kebutuhan belajar yang berbeda. Dalam hubungan yang baik, dosen dan mahasiswa dapat selalu mendiskusikan kebutuhan dan tujuan belajar mahasiswa, serta bekerjasama dalam merencanakan dan mencapai tujuan belajar tersebut (O’Brien, Cooke dan Irby, 2007).

Refleksi merupakan hal yang penting dalam pembelajaran orang dewasa untuk transformasi dan belajar secara kritis. Pembelajaran orang dewasa merupakan suatu proses sosial yang komplek untuk meningkatkan derajat pengalaman diri. Refleksi yang dilakukan bisa refleksi diri sendiri ataupun antar individu. Seorang pebelajar perlu dilibatkan untuk melakukan sesuatu dalam pembelajaran dan mendiskusikan apa yang terjadi pada pembelajaran mereka tersebut (Brockbank dan McGill, 2007).

Hal lain yang didapatkan dari penelitian ini adalah korelasi lemah yang negatif antara lama menjalani rotasi klinik dengan kemampuan belajar mandiri mahasiswa, namun tidak signifikan secara statistik $(p=0,623)$. Hal ini berbeda dengan penelitian di Jerman dan Swedia. Lama rotasi klinik yang ditempuh ini mengindikasikan telah banyak pengalaman klinis yang didapatkan oleh mahasiswa. Penelitian yang dilakukan oleh LummaSellentin di Jerman dan Swedia, menyatakan bahwa banyaknya paparan pengalaman klinis bermanfaat terhadap regulasi diri mahasiswa (LummaSellenthin, 2012). Pada penelitian ini, mahasiswa sebagian besar (82\%) merupakan mahasiswa yang pada saat menempuh sarjana kedokteran menggunakan kurikulum KBK PBL. Perlu penelitian lebih lanjut apakah kurikulum KBK PBL telah berhasil membekali mahasiswa tahap sarjana 
kedokteran dengan kemampuan belajar mandiri yang cukup, sehingga pada saat memasuki pendidikan profesi mempunyai kemampuan belajar mandiri yang memadai. Perlu penelitian lebih lanjut untuk melihat perkembangan kemampuan belajar mandiri sejak awal mahasiswa memasuki tahap pendidikan profesi dan saat mahasiswa berada dalam rotasi klinik.

Saat memasuki rotasi klinik, maka mahasiswa menghadapi banyak tantangan, tidak hanya sekedar tantangan dalam mengaplikasikan ilmu pengetahuan dan ketrampilan. Penyesuaian pada budaya pembelajaran klinik, asumsi tentang tanggung jawab yang lebih besar, proses yang membutuhkan kemampuan belajar mandiri yang lebih tinggi, dan proses yang berkesinambungan dalam adaptasi orang-orang baru, tempat yang berubah-ubah, materi dan ekspektasi yang dibebankan pada mereka. Pada rotasi klinik mahasiswa menempuh pembelajaran dalam stase-stase departemental yang membutuhkan penyesuaian terus menerus. Peran dosen sangat penting dalam menciptakan lingkungan belajar yang dapat mendukung mahasiswa pada proses pembelajaran di tahap profesi ini (O’Brian, Cooke dan Irby, 2007)

Namun demikian, penelitian ini memiliki keterbatasan dalam hal jumlah sampel yang relatif terbatas, meskipun sudah memenuhi kriteria minimal besar sampel dengan rule of thumb untuk penelitian kuantitatif, setelah melakukan restriksi terhadap populasi sumber sampel (Murti, 2006). Hal ini terjadi karena pada satu bagian tersebut hanya 33 mahasiswa yang menempuh stase di bagian tersebut selama waktu dua bulan pengambilan data. Jumlah sampel yang terbatas mungkin mempengaruhi kuasa penelitian ini. Perlu penelitian lebih lanjut dengan menggunakan sampel yang lebih banyak, melibatkan lebih banyak departemen di tahap pendidikan klinik. Selain itu juga tidak ada data awal, tentang kemampuan belajar mandiri mahasiswa saat akan memasuki tahap pendidikan profesi. Namun di sisi lain, hasil penelitian ini dapat menjadi data dasar yang dapat digunakan untuk melihat perkembangan kemampuan belajar mandiri mahasiswa.

Hal lain adalah instrumen yang digunakan merupakan instrumen pengukuran diri sendiri. Menurut Murad dan Varkey, belum ada metode standar dalam pengukuran kemampuan belajar mandiri seseorang, 
walaupun banyak instrumen yang telah dikembangkan. Instrumen yang telah dikembangkan tersebut sama dengan instrumen yang digunakan pada penelitian ini, merupakan pengukuran diri sendiri, misalnya SDLRS yang dikembangkan oleh Guglielmino, OCLI, the Ryan's Quessionairre. Beberapa literatur mengkhawatirkan keakuratan mahasiswa dalam mengisi penilaian diri tentang kebutuhan belajar dan hasil belajar. Pengembangan instrumen pengukuran kemampuan belajar mandiri masih sangat dibutuhkan untuk penelitian di bidang ini (Murad dan Varkey, 2008).

\section{Simpulan}

Simpulan penelitian ini adalah tidak ada perbedaan yang signifikan antara kemampuan belajar mandiri mahasiswa sebelum dan sesudah menjalani pembelajaran tahap pendidikan profesi di salah satu departemen pendidikan profesi. Perlu penelitian lebih lanjut tentang alternatif intervensi yang perlu dilakukan sebagai salah satu cara dalam pengembangan kemampuan belajar mandiri mahasiswa pada tahap pendidikan profesi dokter, juga penelitian serupa dengan menambah jumlah sampel.

\section{Daftar Pustaka}

Abela, J. (2009). Adult Learning Theories and Medical Education: a Review. Malta Medical Journal. Vol. 21. Issue 01. pp 11-18.

Al-Haqwi, A. I., Van der Molen, H. T., Schmidt, H. G., Magzoub, M. E. (2010). Determinants of Effective Clinical Learning: A Student and Teacher Perspective in Saudi Arabia. Education for Health. Vol. 23, Issue 2, pp. 1-14.

Bansal, R. K. (2004). Enhancing Education and Practice, Need for Strengthening of Internship (Rotatory Housemanship) Training in India. Education for Health. Vol. 17, Issue 3, pp. 332-338.

Brockbank, A, McGill, I. (2007). Facilitating Reflective Learning in Higher Education. Second Edition. Mc-Graw Hill: London 
Cox, M., \& Irby, D. M. (2007). "Continuity" as an Organizing Principle for Clinical Education Reform. The New England Journal of Medicine. Vol. 356, Issue 8, pp 858-66.

Devi, V., Devan, D., Soon, P. C., \& Han, W. P. (2012). Comparison of Self-Directed Learning Readiness Among Students Experiencing Hybrid and Traditional Curriculum. Journal of Clinical and Diagnostic Research. Vol. 6, Issue 6, pp. 1047-1050.

Fischer, T, Chenot, J, Simmenroth-Nayda, A, Heinemann, S, Kochen, MM, Himmel, W. (2007). Learning Core Clinical Skills-a Survey at 3 Time Points During Medical Education. Medical Teacher. Vol 29. Hal 397-9

Hays, R. (2005). Teaching and Learning in Clinical Setting. London. Radcliffe Publishing Ltd.

Lee, Y. M. Mann K. V., \& Frank B. W. (2010). What Drives Students' Selfdirected learning in a Hybrid PBL curriculum. Advances in Health Sciences Education. Vol. 15, pp. 425-437.

Murrad, M. H., \& Varkey, P. (2008). Self-directed Learning in Health Professions Education. Annals Academy of Medicine Singapore. Vol. 37, pp. 580-90.

Murti, B. (2006). Desain dan Ukuran Sampel untuk Penelitian Kuantitatif dan Kualitatif di Bidang Kesehatan. h 136. Yogyakarta: Gadjah Mada University Press.

Nara, N. Suzuki, T. Tohda, S. (2001). The Current Medical Education System in The World. J Med Dent Sci. 58. 79-83

O’Brien, B., Cooke, M., \& Irby, D. M. (2007). Perceptions and Attributions of Third-Year Student Struggles in Clerkships: Do Students and Clerkship Directors Agree? Academic Medicine. Vol. 82, pp. 970-978.

Omrod, J. E. (2009). Human Learning. Fifth Edition. New Jersey: Pearson Education 
Reilly, B. M. (2007). Inconvenient Truths about Effective Clinical Teaching. Lancet. Vol. 370, pp. 705-711.

Thornton, K. (2009). Sharing Reflections: Enhancing Learners' Experiences of Self-directed Learning. In A. M. Stoke (Ed.), JALT2009 Conference Proceedings. Tokyo: JALT.

Tsai, T., Lin, C., Harasym P. H., \& Violato, C. (2007). Students' Perception on Medical Professionalism: the Psychometric Perspective. Medical Teacher. Vol. 29, pp. 2-3.

Watmough, S. D., O’Sullivan, H., \& Taylor, D. C. M. (2010). Graduates From a Reformed Undergraduate Medical Curriculum Based on Tomorrow's Doctors Evaluate the Effectiveness of Their Curriculum 6 Years After Graduation Through Interviews. BMC Medical Education. Vol. 10, Issue 65.pp 1-8. 